ISSN 2338-4778 (Print)

ISSN 2548-4192 (Online)

Volume 8, Number 1, June 2020

pp. $126-136$

\title{
Place-Naming (Toponymy) of Kecamatan in Bandung: A Morphological Study
}

\author{
Intan Siti Nugraha*1, Lia Maulia Indrayani² ${ }^{2}$ Ypsi Soeria Soemantri ${ }^{3}$ \\ * intan19004@mail.unpad.ac.id \\ 1, 2,3 English Linguistics, Faculty of Cultural Sciences, \\ Universitas Padjadjaran, Sumedang, Indonesia
}

Received: 7 May 2020 Accepted: 16 May 2020

DOI: $10.24256 /$ ideas.v8i1.1325

\begin{abstract}
This study aims to analyze the morphological processes occupied in place-naming of Kecamatan in Bandung and attempts to classify the place-naming of Kecamatan in Bandung based on toponymy rules by Nash (2015). Descriptive qualitative research design was employed in this study. The investigation of thirty names of Kecamatan in Bandung shows that there are only three types of morphological process in naming Kecamatan in Bandung. They are compounding, borrowing and blending. In term of toponymy rules, the patterns are various in each morphological process: (1) A Single (Proper) Noun; (2) Two Nouns: (Generic) Noun + (Proper) Noun; and (3) (Proper) Noun + Adjective.
\end{abstract}

Keywords: morphological process; place-naming

\section{Introduction}

Place-naming is closely related to discuss toponymy, a sub-field of onomastics. Toponymy is a study about the origin of place name (Kusuma et al., 2008; Gunadi et al., 2015). In Meriam-Webster Dictionary, toponymy is the place-name of a region or language or especially the etymological study of them. Study of place name can be analyzed from linguistic domain, semantically or grammatically (Nash, 2015). He asserts that toponymy comprises a distinct conceptual and semantic domain, separate from lexical and grammatical domain of language.

Shoval (2013) remarks that name of places commemorate historical events, narratives, or people and also reflect geographical space. The names can be in form of simplex word or complex word or series of word as identity of the place that distinguish from others (Alderman, 2016). Not only on the name itself, in the process of giving name, there is always meaning behind it, place-naming (Kusuma, et al., 2008) since language is a cultural symbol which is adherent to the ethnics 
(Usman \& Nurkholik, 2018).

Different ethnic, cultural group living in a city may give different place names that are important for them portrayed as accepted history and heritage by them (Shoval, 2013). In Bandung, place-naming is closely related to the origin of Bandung. The name of Bandung is originated from the word bandung which means 'contiguous'. It refers to the contiguous lands, the bank of Citarum river and the shore of The Old Great Lake of Bandung or Situ Hyang (Kulsum, et al., 2008). Sundanese people who lived there believed that Bandung is fertile region and closely connected to the plenty of water springs. It was reflected on the name of places in Bandung.

The research on investigating the names of Sundanese area have been concerned by some researchers such as Bachtiar (2005), Kulsum et al. (2008), Gunadi et al. (2015) and Sujatna et al. (2016). Some of them used anthropolinguistics approach, some others concerned on linguistics features such as morphology and semantics. Study conducted by Bachtiar (2005) and Kulsum et al. (2008) were concerned on place-naming in Sundanese area (Parahyangan), including Bandung area, using anthropolinguistics approach. Bachtiar (2005), however, is very limited on common geographical names in Bandung and its histories with very simple linguistic analysis. Fortunately, Kulsum et al. (2008) dig deeper analysis on place-naming in which more places in Bandung were revealed with interconnected to culture and social culture of the places.

Different from Bachtiar (2005) and Kulsum et al. (2008), Sujatna et al. (2016) carried out a study of place-naming on the morphological processes. They discuss morphological processes of Jawa Barat tourism destinanion naming. The result showed that there were only five morphological processes from ten morphological processes on tourism destination place-naming in Jawa Barat. They are acronym, blending, coinage, compounding and borrowing. Another study conducted by them on toponymy analysis. They further investigated the tourism place-naming and classified them on Nash (2015) classification of rules for English language toponymy. It was found that there were three types of place-naming. They are single (proper) noun, two nouns with (Generic) Noun + (Proper) Noun order, and (Proper) Noun + Adjective. In term of morphological processes, they are compounding, borrowing and blending.

Derived from preceding elaboration of former research on place-naming, especially place naming in Bandung, this study focuses on analyzing morphological process in naming Kecamatan in Bandung and their place-naming (toponymy) classification based on Nash's rules of toponymy.

\section{Method}

In accordance with the purpose of the research related to analyzing the morphological processes occupied in place-naming of Kecamatan in Bandung and classify them based on typonomy classification of Nash (2015), the research employed descriptive qualitative research design since it places stress and 
describes in detail of certain phenomenon through textual analysis and interpretation rather than comparing the effects of a particular treatment (Burns, 1995; Creswell, 1994; Fraenkel, Wallen, \& Hyun, 2012).

The data was names of Kecamatan in Bandung taken from Bandung government official website, Pejabat Pengelola Informasi dan Dokumentasi Kota Bandung. The name list of Kecamatan is retrieved from https://ppid.bandung.go.id/knowledgebase/data-kecamatan-di-kota-bandung/. There are 30 names of Kecamatan in Bandung.

In conducting the research, there were several steps undergone by the researcher. Firstly, after the names of Kecamatan were collected, each name was analyzed in terms of their morphological process occupied and place-naming classification based on Nash's toponymy rules. Nash's toponymy rules of place-naming, are as follows:

1. A single English (proper) noun is productive, e.g. Cascade, Codrington, Arcadia, Possum.

2. (Proper) noun + (generic) noun (+ noun) is productive, e.g. Headstone (mono-lexemes), Pole Point, Charlotte Field, Ball Bay, Hurlstone Park (bi-lexemes), Selwyn Pine Reserve (tri-lexemes).

3. Numeral (+ noun) (+ noun) is productive (e.g. Nine Acre Piece, One Hundred Acre, 77, Four Square.

4. Adjective + noun is productive (e.g. Middlegate (monolexemes), Big House, Rocky Point, New Ground, Bloody Bridge (bilexemes)).

5. Adjective + noun + noun is productive, e.g. New Farm West.

6. Definite article + adjective (+ generic noun) is productive, e.g. The Big Flat.

7. Adjective + (generic) noun is productive, e.g. Little Cascade, Fat Gulley.

8. (Proper) noun + possessive + noun is productive, e.g. Sheres Gulley, Clitchers Corner, Burns Farm, Collins Head, Steels Point.

9. Generic noun + proper noun is productive, e.g. Mount Pitt, Lake Ayliffe.

10. Proper noun (+ proper noun) + possessive is productive, e.g. Barney Duffys, Ragseys.

11. There are fishing grounds that have arisen through humour, e.g. Oodles (where you catch oodles of fish), No Trouble Reef, No Reason, and Horse and Cart.

\section{Results}

Data collected are the names of kecamatan in Bandung. There are 30 kecamatan names. All the data were analyzed in terms of their morphological composition based on Nash's toponymy rules and the morphological process involved in the names. The findings are presented in the table below: 
Table 1. Morphological Process and Place-Naming Classification

\begin{tabular}{cc}
\hline Morphological Process & Place-Naming Classification \\
\hline Compounding & A Single (proper) Noun \\
Borrowing & Two Nouns: (Generic) Noun + (Proper) Noun \\
Blending & (Proper) Noun + Adjective \\
\hline
\end{tabular}

Table 1 shows that there are only three types of morphological process and three classification of toponymy based on Nash's rules in naming Kecamatan in Bandung. The morphological process are compounding, borrowing and one only blending while Nash's toponymy are A Single (proper) Noun, Two Nouns: (Generic) Noun + (Proper) Noun, and (Proper) Noun + Adjective

\section{Discussion}

\section{Morphological Process of Place-Naming}

Data collected are the names of kecamatan in Bandung. There are 30 kecamatan names. All the data were analyzed in terms of their morphological composition based on Nash's toponymy rules and the morphological process involved in the names. There are only three types of morphological process in naming Kecamatan in Bandung. They are compounding, borrowing and one only blending.

Compounds are words that are composed of two (or more) bases, roots, or stems (McCarthy, 2002; Liber, 2009). A compound word can be formed by two or more words. The compounding words used as place name of Kecamatan in Bandung are various in forms of pattern, such as Noun+Nound compound, Noun+Adjective compound, and Noun+Verb compound. There were also found names in juxtaposed position such as Gedebage, which in the compounding formation, the noun is preceded by adjective. The borrowing names are taken from Sundanese language.

The most dominant morphological process in place-naming of kecamatan in Bandung is compounding. From the 30 names of Kecamatan in Bandung, there are 23 names which involve compounding in the place-naming. Borrowing process is found in five names. Meanwhile the rarest morphological process is blending, which is found in one name of Kecamatan.

\section{Place-Naming (Toponymy) Classification}

In this subsection, the findings will be further discussed based on the classification of Nash's toponymy rules and the morphological processes of the names.

\section{A Single (proper) Noun}

The first classification of kecamatan names in Bandung based on Nash's 
toponymy rules is single (generic) noun. There are 19 names categorized as single (generic) noun. The analysis of the 19 names of Kecamatan in Bandung si presented below:

Table 2. Morphological process of A Single (proper) Noun Classification

\begin{tabular}{|c|c|c|c|c|}
\hline No. & $\begin{array}{c}\text { Name of } \\
\text { Kecamatan }\end{array}$ & $\begin{array}{c}\text { Morphological } \\
\text { Composition } \\
\text { (Nash's Typonomy } \\
\text { Rules) }\end{array}$ & Meaning & $\begin{array}{c}\text { Morphological } \\
\text { Process }\end{array}$ \\
\hline \multirow[t]{3}{*}{1.} & & (Generic) Noun & & \\
\hline & Andir & & & Borrowing \\
\hline & & Andir & Water spring & \\
\hline \multirow[t]{2}{*}{2.} & & (Generic) Noun + (Generic) & & \\
\hline & Coblong & $\begin{array}{l}\text { Noun } \\
\mathrm{Ci}+\mathrm{Nambo}\end{array}$ & $\begin{array}{c}\text { A place to store } \\
\text { water }\end{array}$ & Borrowing \\
\hline \multirow[t]{3}{*}{3.} & & (Generic) Noun & & \\
\hline & Lengkong & & & Borrowing \\
\hline & & Lengkong & Lake & \\
\hline \multirow[t]{2}{*}{4.} & & (Generic) Noun & & \\
\hline & Panyileukan & Panyileukan & $\begin{array}{c}\text { Something } \\
\text { waited/hoped }\end{array}$ & Borrowing \\
\hline \multirow[t]{3}{*}{5.} & & (Generic) Noun & & \\
\hline & Regol & & & Borrowing \\
\hline & & Regol & Entrance & \\
\hline \multirow[t]{3}{*}{6.} & & Adjective + (Generic) Noun & & \\
\hline & Gedebage & & & Blending \\
\hline & & Gede + Bagea & Big + Luck & \\
\hline \multirow[t]{3}{*}{7.} & & Generic) Noun + (Generic) & & \\
\hline & Arcamanik & Noun & Statue + Pearl & Compounding \\
\hline & & Arca + manik & & \\
\hline \multirow[t]{3}{*}{8.} & & (Generic) Noun + Adjective & & \\
\hline & Batununggal & & & Compounding \\
\hline & & Batu + Nuggal & Rock + United & \\
\hline \multirow[t]{3}{*}{9.} & & (Generic) Noun + (Generic) & & \\
\hline & Buahbatu & Noun & Manggo + Rock & Compounding \\
\hline & & Buah + Batu & & \\
\hline \multirow[t]{2}{*}{10.} & & (Generic) Noun + (Generic) & & \\
\hline & Cibiru & $\begin{array}{l}\text { Noun } \\
\mathrm{Ci}+\mathrm{Biru}\end{array}$ & $\begin{array}{l}\text { Water + Biru } \\
\text { (name of fruit) }\end{array}$ & Compounding \\
\hline
\end{tabular}


IDEAS, Vol. 8, No. 1, June 2020

ISSN 2338-4778 (Print) ISSN 2548-4192 (Online)

\begin{tabular}{|c|c|c|c|c|}
\hline No. & $\begin{array}{c}\text { Name of } \\
\text { Kecamatan }\end{array}$ & $\begin{array}{c}\text { Morphological } \\
\text { Composition } \\
\text { (Nash's Typonomy } \\
\text { Rules) }\end{array}$ & Meaning & $\begin{array}{l}\text { Morphological } \\
\text { Process }\end{array}$ \\
\hline 11. & & (Generic) Noun + (Generic) & & \\
\hline & Cicendo & Noun & & Compounding \\
\hline & & $\mathrm{Ci}+$ Cendo & Water + eyes & \\
\hline 12. & Cidadap & $\begin{array}{l}\text { (Generic) Noun }+ \text { (Proper) } \\
\text { Noun } \\
\text { Ci + Dadap }\end{array}$ & $\begin{array}{l}\text { Water + Dadap } \\
\text { (name of plant) }\end{array}$ & Compounding \\
\hline 13. & Cinambo & $\begin{array}{l}\text { (Generic) Noun }+ \text { (Generic) } \\
\text { Noun } \\
\mathrm{Ci}+\mathrm{Nambo}\end{array}$ & $\begin{array}{c}\text { Water + banks } \\
\text { of river }\end{array}$ & Compounding \\
\hline 14. & Kiaracondong & $\begin{array}{l}\text { (Generic) Noun + Adjective } \\
\text { Kiara }+ \text { Condong }\end{array}$ & $\begin{array}{l}\text { Kiara (name of } \\
\text { tree) + sloping }\end{array}$ & Compounding \\
\hline 15. & Mandalajati & $\begin{array}{l}\text { (Generic) Noun }+ \\
\text { Adjective } \\
\text { Mandala }+ \text { Jati }\end{array}$ & Area + Loyal & Compounding \\
\hline 16. & Rancasari & $\begin{array}{l}\text { (Generic) Noun }+(\text { Generic }) \\
\text { Noun } \\
\text { Ranca }+ \text { Sari }\end{array}$ & $\begin{array}{c}\text { Downstream + } \\
\text { Sense }\end{array}$ & Compounding \\
\hline 17. & Sukajadi & $\begin{array}{l}\text { (Generic) Noun + (Generic) } \\
\text { Noun } \\
\text { Suka + Jadi }\end{array}$ & Love + Pottery & Compounding \\
\hline 18. & Sukasari & $\begin{array}{l}\text { (Generic) Noun + (Generic) } \\
\text { Noun } \\
\text { Suka + Sari }\end{array}$ & Love + Sense & Compounding \\
\hline 19. & Ujungberung & $\begin{array}{l}\text { (Generic) Noun + Verb } \\
\text { Ujung + Berung }\end{array}$ & End + Get angry & Compounding \\
\hline
\end{tabular}

Table-2 shows that there are five names which undergo borrowing morphological process in the naming. Borrowing according to Hoffer (2002) is the process of importing linguistic items from one linguistic system into another, a 
process that occurs any time two cultures are in contact over a period of time. In other words, borrowing or sometimes called loan word is a process of borrowing from one language to others. In this finding, the five borrowing names of Kecamatan are loan words from Sundanese language. They are Andir, Coblong, Lengkong, Panyileukan, and Regol. In Sundanese, andir, coblong, and lengkong are closely related to water. Andir means water spring while Coblong is 'a place to store water'. According to Kulsum, et al. (2008) lengkong's meaning refers to a 'lake or place with plenty of water'. Differ from the three names, panyileukan has meaning as 'something waited or hoped'. Bachtiar (2005) explains the meaning of regol as part of Bandung new village construction in the past which regol means entrance of the new village.

In this classification, it is also found a blending process as in Gedebage. Blending is a process of word formation in which parts of lexemes that are not themselves morphemes are combined to form a new lexeme (Lieber, 2009). As shown in Table-1, Gedebage is formed from two free morphemes of Sundanese, which are gede and bagea. In Gedebage, the words gede and bagea are blended with partial blend. It is where only one component is truncated (McCarthy, 2002) that is the sound $a$ in word bagea undergoes reduction.

Other 13 names of Kecamatan in Bandung categorized as single (proper) noun involve compounding in forming names. They are Arcamanik, Batununggal, Buahbatu, Cibiru, Cicendo, Cidadap, Cinambo, Kiaracondong, Mandalajati, Rancasari, Sukajadi, Sukasari, and Ujungberung. These 13 names are combination of two words of Sundanese language. The forms of words combined are various. They are (generic)Noun + (generic) Noun compounds such as Arcamanik, Buahbatu, Cicendo, Cinambo, Mandalajati, Rancasari, Sukajadi, Sukasari, (generic)Noun + (proper)Noun compounds such as Cibiru and Cidadap, (generic)Noun + Adjective compounds such as Batununggal and Kiaracondong and (generic)Noun + Verb compound such as Ujungberung.

The example of (generic)Noun + (generic) Noun compounds is Arcamanik. Arcamanik is a compound words from generic noun arca which means 'statue' and generic noun manik which means 'pearls'. Cidadap which is (generic)Noun + (proper)Noun compound, is a combination of generic noun ci which in English is 'water' and proper noun Dadap. Dadap is a name of a tree (Fabaceae). Kiaracondong is different from the two compound forms. It is a combination of generic noun Kiara which is 'fig tree' (Ficus carica) and an adjective of condong which means 'sloping'. In last compound form of single (proper) noun is (generic)Noun + Verb compound found in Ujungberung. Ujungberung is formed from word ujung which means 'end' and word berung from ngaberung which is 'getting angry'.

Two Nouns: (Generic) Noun + (Proper) Noun

The classification applied in this study slightly different from Nash's rules. The 
difference is the adaptation attempt to the data found. Nash (2015) classifies two nouns with different order from the order used in this study as in Sujatna (2016). In Nash's classification puts generic noun after proper noun. In this study, however, in the findings, generic noun appears before proper noun as shown in the Table 3 below:

Table 3. Morphological process of Two Nouns Classification

\begin{tabular}{|c|c|c|c|c|}
\hline No. & $\begin{array}{c}\text { Name of } \\
\text { Kecamatan }\end{array}$ & $\begin{array}{c}\text { Morphological } \\
\text { Composition } \\
\text { (Nash's Typonomy } \\
\text { Rules) } \\
\end{array}$ & Meaning & $\begin{array}{c}\text { Morphological } \\
\text { Process }\end{array}$ \\
\hline 1. & $\begin{array}{l}\text { Babakan } \\
\text { Ciparay }\end{array}$ & $\begin{array}{l}\text { (Generic) Noun }+ \\
{[(\text { Generic) Noun }+ \text { (proper) }} \\
\text { Noun })]\end{array}$ & $\begin{array}{c}\text { New village }+ \\
{[\text { water+Paray] }}\end{array}$ & Compounding \\
\hline 2. & $\begin{array}{l}\text { Sumur } \\
\text { Bandung }\end{array}$ & $\begin{array}{l}\text { (Generic) Noun + (Generic) } \\
\text { Noun } \\
\text { Sumur + Bandung }\end{array}$ & Well + Bandung & Compounding \\
\hline
\end{tabular}

The name of kecamatan in Bandung classified in this place-naming are Babakan Ciparay and Sumur Bandung. Babakan and sumur are generic nouns. Meanwhile both Ciparay and Bandung are proper nouns. Babakan's meaning in English is 'new village' and sumur is 'well'. Morphological process in both names is compounding. Sumur Bandung is combination of sumur and Bandung which is the name of city. Interestingly, in Babakan Ciparay, there is compound word within the compound. Babakan Ciparay is combination of Babakan and Ciparay. Ciparay is actually a compound word. McCarthy (2002) explains compounding within a compound word is common to happen. Accordance with McCharty, the compound word within compound names is occupied in some place-naming of Sundanese regions. The example is found in this Babakan Ciparay.

(Proper) Noun + Adjective

In addition, the data obtained are also categorized into a combination of two different word classes as in Nash's classification. This last classification is a combination of proper noun and adjective. There are seven names of Kecamatan in Bandung found using this form. They are Bandung Kidul, Bandung Kulon, Bandung Wetan, Bojongloa Kaler, Bojongloa Kidul, CIbeunying Kaler and Cibeunying Kidul. Mophological proceses undergo are presented in the table below: 
Intan Siti Nugraha, Lia Maulia Indrayani, Ypsi Soeria Soemantri

Place-Naming (Toponymy) of Kecamatan in Bandung: A Morphological Study

Table 4. Morphological process of (Proper) Noun + Adjective Classification

\begin{tabular}{|c|c|c|c|c|}
\hline No. & $\begin{array}{c}\text { Name of } \\
\text { Kecamata } \\
\text { n }\end{array}$ & $\begin{array}{c}\text { Morphological } \\
\text { Composition } \\
\text { (Nash's Typonomy } \\
\text { Rules) }\end{array}$ & Meaning & $\begin{array}{l}\text { Morphological } \\
\text { Process }\end{array}$ \\
\hline 1. & $\begin{array}{l}\text { Bandung } \\
\text { Kidul }\end{array}$ & $\begin{array}{l}\text { (Generic) Noun + Adjective } \\
\text { Bandung + Kidul }\end{array}$ & $\begin{array}{c}\text { Name of City + } \\
\text { South }\end{array}$ & Compounding \\
\hline 2. & $\begin{array}{l}\text { Bandung } \\
\text { Kulon }\end{array}$ & $\begin{array}{l}\text { (Generic) Noun + Adjective } \\
\text { Bandung + Kulon }\end{array}$ & $\begin{array}{c}\text { Name of City + } \\
\text { West }\end{array}$ & Compounding \\
\hline 3. & $\begin{array}{l}\text { Bandung } \\
\text { Wetan }\end{array}$ & $\begin{array}{l}\text { (Generic) Noun + Adjective } \\
\text { Bandung + wetan }\end{array}$ & $\begin{array}{c}\text { Name of City + } \\
\text { East }\end{array}$ & Compounding \\
\hline 4. & $\begin{array}{l}\text { Bojongloa } \\
\text { Kaler }\end{array}$ & $\begin{array}{l}\text { [(Generic) Noun }+ \text { (proper) } \\
\text { Noun }] N+\text { Adjective } \\
{[\text { Bojong }+ \text { Loa }]+\text { Kaler }}\end{array}$ & $\begin{array}{l}\text { [Riverbank + } \\
\text { Loa (type of } \\
\text { tree)]+North }\end{array}$ & Compounding \\
\hline 5. & $\begin{array}{l}\text { Bojongloa } \\
\text { Kidul }\end{array}$ & $\begin{array}{l}{[(\text { Generic }) \text { Noun }+ \text { (proper })} \\
\text { Noun }]+ \text { Adjective } \\
{[\text { Bojong }+ \text { Loa }]+\text { Kidul }}\end{array}$ & $\begin{array}{l}\text { [Riverbank + } \\
\text { Loa (type of } \\
\text { tree)]+south }\end{array}$ & Compounding \\
\hline 6. & $\begin{array}{l}\text { Cibeunying } \\
\text { Kaler }\end{array}$ & $\begin{array}{l}{[(\text { Generic }) \text { Noun }+ \text { (proper })} \\
\text { Noun }]+ \text { Adjective } \\
{[C i+\text { Beunying }]+\text { Kaler }}\end{array}$ & $\begin{array}{l}\quad \text { [water + } \\
\text { Beunying (name } \\
\text { of tree)] + North }\end{array}$ & Compounding \\
\hline 7. & $\begin{array}{l}\text { Cibeunying } \\
\text { Kidul }\end{array}$ & $\begin{array}{l}{[(\text { Generic }) \text { Noun }+ \text { (proper })} \\
\text { Noun }]+ \text { Adjective } \\
{[\mathrm{Ci}+\text { Beunying }]+\text { Kidul }}\end{array}$ & $\begin{array}{c}\text { [water + } \\
\text { Beunying (name } \\
\text { of tree)] + south }\end{array}$ & Compounding \\
\hline
\end{tabular}

Looking at the morphological process and their composition in Table 4, all of the adjectives following proper nouns in those names are wind directions, such as kidul which means 'south', kaler which means 'north', kulon which mean 'west' and wetan which means 'east'. In addition, the morphological process in the seven names above is compounding. Five names of Kecamatan are similar with Babakan Ciparay. They are formed from compound word within compound word. They are Bojongloa Kaler, Bojongloa Kidul, CIbeunying Kaler and Cibeunying Kidul. Bojongloa is a compound word from bojong and loa. Bojong in English is 'bank river' and Loa is a name of a tree (ficus racemosa). Cibeunying is a compound word from ci which means 'water' and 'beunying' is name of tree (Ficus fistulosa). 


\section{Conclusion}

Based on the result and discussion, it can be concluded that there are three types of place-naming of Kecamatan in Bandung and three morphological processes involved. Adapted from Nash's classifications of place -naming, names of Kecamatan in Bandung are categorized into single (proper) noun, two nouns with (Generic) Noun + (Proper) Noun order, and (Proper) Noun + Adjective. In term of morphological processes, they are compounding, borrowing and blending.

According to the research findings and conclusion, some suggestions are proposed to future research and studies related to the topic:

1. The investigation of place-naming or toponymy in in term of its linguistic features such as morphology and semantics is also important to conduct.

2. The combination of approaches in studying place-naming is also suggested such as anthropolinguistics to get deeper analysis.

3. Other researchers who are interested to the same topic can develop the wider scope in term of object studied.

\section{References}

Alderman, D. H. (2016). Place, naming and the interpretation of cultural landscapes. Heritage and Identity, edited by Brian Graham and Peter Howard, 195-213.

Bachtiar, T. (2005). Mengenal asal-muasal nama tempat di cekungan Bandung I. Pikrian Rakyat, 22 Agustus 2005.

Bachtiar, T. (2005). Mengenal asal-muasal nama tempat di cekungan Bandung II (Habis). Pikrian Rakyat, 29 Agustus 2005.

Burns, R. B. (1995). Introduction to research methods. Melbourne: Longman Australia Pty Ltd.

Creswell, J. W. (1994). Research design: qualitative and quantitative approach. California: Sage Publication Inc.

Fraenkel, J. R., Wallen, N. E., \& Hyun, H. H. (2012). How to design and evaluate research in education (8th Edition ed.). New York: McGraw-Hill.

Gunardi, G., Mahdi, S., Ratnasari, D., \& Sobarna, C. (2015). Toponimi dan Lingkungan Hidup Kampung Adatdi Tatar Sunda (Bandung). In Seminar Nasional Riset Inovatif (Vol. 3).

Hoffer, B. L. (2002). Language borrowing and language diffusion: An overview. Intercultural communication studies, 11(4), 1-37.

Kulsum, U. (2008). Nama tempat di Kota Bandung yang berhubungan dengan air: Tinjauan antropolinguistik. Bandung: Balai Bahasa Bandung.

Lieber, R. (2009). Introducing morphology. Cambridge University Press. 
McCarthy, A. C. (2002). An introduction to English morphology: words and their structure. Edinburgh: Edinburgh University Press.

Nash, J. (2015). Is toponymy necessary?. Studies in Language. International Journal sponsored by the Foundation "Foundations of Language", 39(1), 230-235.

Shoval, N. (2013). Street-naming, tourism development and cultural conflict: the case of the Old City of Acre/Akko/Akka. Transactions of the Institute of British Geographers, 38(4), 612-626.

Sujatna, E., \& Pamungkas, K. (2016). Place-naming of tourism destinations in Jawa Barat: A toponymy study. International E-Journal of Advances in Social Sciences, 2(5), 471-476.

Usman, N., \& Nurkholik. (2018). The morphological processes of Bugis's language (a morphological study of Bugis language through Latoa script). IDEAS: Journal on English Language Teaching and Learning, Linguistics and Literature, 6(1), 17-25.

https://ppid.bandung.go.id/knowledgebase/data-kecamatan-di-kota-bandung/ 